\title{
Barriers to the Implementation of Education for Sustainable Development in Namibia's Higher Education Institutions
}

\author{
Alex Kanyimba, Miriam Hamunyela, Choshi D. Kasanda \\ University of Namibia, Windhoek, Namibia \\ Email: akanyimba@unam.na, mhamunyela@unam.na, ckasanda@unam.na
}

Received 7 December 2013; revised 7 January 2014; accepted 14 January 2014

Copyright (C) 2014 by authors and Scientific Research Publishing Inc.

This work is licensed under the Creative Commons Attribution International License (CC BY). http://creativecommons.org/licenses/by/4.0/ (c) (7) Open Access

\begin{abstract}
One of the challenges of education for sustainable development in Namibian higher education institutions concerns the practice and linkage thereof to other initiatives in education and learning. This paper reports on research into barriers to the implementation of the interdisciplinary model of education for sustainable development in Namibian higher education institutions. The collected data were analysed by means of Microsoft Excel spread sheets and consistent observation of qualitative data. The results show the main barriers to be dispositional, situational and institutional. The members of management in Namibian higher education institutions must be convinced about the importance of education for sustainable development and urged to develop a policy that can be used as an extension for on-the-job training of lecturers. It is necessary to learn from other higher education institutions around the world how they implemented education for sustainable development in their respective institutions. Lecturers should be urged to use this experience to develop resources for implementing education for sustainable development in Namibian higher education institutions.
\end{abstract}

\section{Keywords}

Education for Sustainable Development; Environmental Education; Namibian Higher Education Institution

\section{Introduction}

The United Nations Conference on Environment and Development (UNCED) highlighted the potential role of education in relation to sustainable development (Rickinson, Lundholm, \& Hopwood, 2009). Chapter 36 of 
Agenda 21 asserts that "Education, including formal education, should be recognised as a process by which human beings and societies can reach their fullest potential. Education is critical for promoting sustainable development and achieving environmental and ethical awareness, values and attitudes, skills and behaviour consistent with environmental protection” (Earth Summit, 1992: p. 221). The World Summit on Sustainable Development (WSSD), held in Johannesburg in 2002, put in place Resolution 57/254 in which the United Nations Decade of Education for Sustainable Development (UNDESD) was proposed. The DESD runs from 2005-2014 and seeks to implement Education for Sustainable Development (ESD) in the education curricula. This decade speaks to the bridges that must be built between academia and community needs, as well as the need to enact sustainability in higher education in a manner that affects society at large and the biosphere positively (Cortese \& McDonough, 2003). The goal of ESD is to transform environmental, social and economic aspects of society to sustainable levels (Down, 2006).

Namibia joined the rests of the world in conceiving how the UNDESD could be realised in Namibian Higher Education Institutions (HEIs). The Green Plan, Namibia's blue print for sustainable development, which was presented at the United Nations Conference on Environment and Development (UNCED, MWCT, 1992) and the First National Consultative Seminar on Education for Sustainable Development in Namibia (NATCOM, 2008), expressed the following: Namibian higher education institutions (HEIs) need to mainstream ESD into the education, research and development programmes. The Consultative Seminar furthermore urged HEIs in Namibia to educate and train people who would have the capacity to innovate and provide appropriate knowledge and technological solutions for sustainable development.

The introduction of ESD into Namibian formal education has started to emerge in a structured and strategic way (Ministry of Environment \& Tourism, 2002). Steps taken, among others, are the inclusion of certificate level environmental education courses in the College for Open and life-long Learning, addressing environmental issues through the School of Natural Resources and Tourism and the School of Health and Applied Sciences at the Polytechnic of Namibia (PoN) (Polytechnic of Namibia, 2012a,b,c). The University of Namibia's (UNAM) Faculty of Education has introduced EE modules in the B.Ed Lower Primary and in the B.Ed Adult Education courses. Other courses in the Faculties of Science and Law as well as the Department of Geography and Environmental Studies at UNAM are carriers of ESD subject matter (University of Namibia, 2011a,b,c,d). From the above it is apparent that ESD in Namibian HEIs has been implemented in traditional environmental subjects. Thus it is stated in the Namibia First Consultative Report on Education for Sustainable Development, (NATCOM, 2008: p. 8) that the one challenge of ESD in Namibia concerns the meaning and interpretation of the concept, its practice and its linkages to other initiatives in education and learning. The research addressed by this study sought to find out the barriers that affect ESD in this regard.

Taking the above into consideration, it is important for lecturers in the Namibian higher education sector to understand the need to cross the disciplinary boundary in the planning, teaching and assessment of ESD, to discover the difficulties in the implementation of ESD in Namibia's HEIs. The understanding and views of lecturers are significant for the practice and its linkages to other initiatives in education and learning, as these could inform ESD practices beyond the UNDESD (Barth, Godemann, Rieckmann, \& Stoltenberg, 2007; Rove, 2007).

The aim of this study therefore was to assess the barriers to the implementation of ESD in Namibian HEIs from a Namibian perspective. To reach this aim, the remainder of this article follows this sequence:

- The statement of the problem is presented;

- The theoretical framework on which the investigation was based is discussed;

- The exposition of the research design, strategy and methods;

- The presentation and interpretation of the results;

- Discussions are presented in view of the theoretical framework;

- Recommendations to address the barriers in the Namibian higher education institutions.

\section{Statement of the Problem}

Since the Earth Summit of 1992, ESD has gained a higher profile within higher education (Cotton, Bailey, Warren, \& Bissell, 2009). However, in Namibian HEIs, ESD is a concept that seems to be struggling to get off the ground and be implemented at all levels of higher education (MWCT, 1992; NATCOM, 2008). What this study sought was to investigate barriers hindering the implementation of ESD and how these barriers should be ad- 
dressed in Namibian HEIs. The following three research questions were addressed:

- What are the lecturers' views regarding the incorporation of ESD in Namibian HEIs?

- What are the barriers hindering the implementation of ESD in Namibian HEIs?

- How should these barriers be addressed to effectively implement ESD in Namibian HEIs?

\section{Theoretical Framework}

The role, status and scope of ESD are contained in the Namibian Constitution (Ministry of Information and Broadcasting, 1990), the Namibia Vision 2030 (Government of the Republic of Namibia, 2004), the National Curriculum for Basic Education, Namibian Environmental Education/Education for Sustainable Development policy (Ministry of Education, 2009) and other key Namibian national curriculum documents. For the purpose of this research, ESD is defined as the intellectual tasks of critically appraising environmental situations and the formulation of an ethical code to address the environmental situations through the various courses in the Namibian HEIs. The authors put forward the notion of ESD that is both instrumental and emancipatory (Wals, 2003): Instrumental because it recognises the environmental knowledge and skills, attitude and values needed to orientate Namibian HEIs towards education for sustainable development. Emancipatory in that it reflects the need to create space for every course in Namibian HEIs to address environmental issues and space for individual lecturers to engage with environmental issues.

The study of the barriers to the implementation of ESD in Namibian HEIs was informed by the ecosystem theory (Nielsen, 2007), because it sought to promote space for the interdisciplinary implementation of ESD within and beyond the various courses taught in various departments of Namibian higher education. Many versions of ecosystem theories can be found in the literature (Jørgensen, 2002). The focus of the ecosystem theory adopted in this study therefore evolved from a blend of post-modern ecological world views and system thinking theories of education (Anker, 2002; Sterling, 2003; Donald, Lazarus, \& Lolwana, 2006; Preisendỏrfer, 2008). Sterling (2003) posits that the post-modern ecological worldview has profound implications for the visioning and realisation of a more sustainable society. System thinking is a mode of thinking which embraces the relationship and comprehensive treatment of all parts of a system (Sterling, 2003). The ecosystem theory therefore provides an insight into the relationship between natural systems and human systems (Cutter \& Renwick, 2004; Jørgensen, 2002). For the purpose of this report, natural systems include environmental issues of water, energy, waste, transport, climate change, biodiversity and many others. These issues need to be integrated into the human system, which include the subjects of Namibian higher education, the teaching resources, knowledge, skills, attitudes and values of the lecturers in Namibian HEIs.

The relevance of the ecosystems theory in this study is the recognition that the courses taught in Namibian higher education are connected with ESD. In the context of Namibian higher education the study therefore promotes an ecosystem-orientated pedagogy because it facilitates the inter-disciplinary planning, teaching and assessment of ESD in Namibian higher education (Sipos, Battisti, \& Grimm, 2006). It facilitates the links between the natural and human systems in the education and learning process. The link emphasised in this context pertains to implementation of natural systems in the different courses of Namibian HEIs.

Deficiencies of the ecosystem theory are that it is assumed to be untested, the belief that social values should not be integrated with natural data and thus must be excluded from an ecological inquiry its difficulty to explain the large variation of localities (Seehausen, 2007; Austin, 2007) These weakness would not apply in ecosystem-orientated pedagogy which seeks to create space for emancipation and the introduction of the social dimension in ecological inquiry (Glaser, 2006). The authors hold the view that emancipation and social dimension create abilities for testing the theory through all lecturers' participation in planning and teaching and assessment of ESD. Furthermore, the ecological inquiry is social because it addresses the lecturers' view that would lead to creating space for natural systems in the various courses of Namibian HEIs.

This study was launched among a sample of lecturers in Namibian HEIs following the above theoretical framework.

\section{Research Design, Strategy and Methods}

The empirical investigation was embedded in the mixed research design paradigm because it simultaneously presents numerical and non-numerical data relating to the barriers to the implementation of ESD in Namibian HEIs from a Namibian perspective (Creswell, 2009; Johnson \& Christensen, 2004; Gall, Gall, \& Borg, 2010; 
Walsh, 2001). A concurrent embedded research strategy (Creswell, 2009) was used because the questionnaire consisted of open-ended questions to broaden the perspectives with regard to the aim of this study.

\subsection{Population and Sampling}

The population of the study was all the lecturers at the University of Namibia (UNAM), Polytechnic of Namibia (PoN), and the International University of Management (IUM). Stratified sampling (Walliman, 2005; Mertler \& Charles, 2011; Johnson \& Christensen, 2004) was used because the lecturers were selected from the different faculties. The main stratification variable used was the faculties and the departments in which the lecturers work. A total of 52 lecturers formed the sample for this study.

\subsection{The Survey}

To answer the afore-mentioned research questions, a survey was initiated to collect data from the lecturers using a structured questionnaire (Creswell, 2009) consisting of close-ended and open ended questions which sought to find out the barriers hindering the integration of ESD as perceived by lecturers in Namibian higher education contexts.

\subsection{Data Collection Process, Analysis and Limitations}

The data collection period at the four campuses of the University of Namibia, one campus of the Polytechnic of Namibia and International University of Management proceeded over a period of one year. The administrations of questionnaires to the lecturers on these campuses were facilitated by the office of Academic Affairs and Research of these respective institutions. One hundred (100) questionnaires were distributed, of which only fifty two (52) questionnaires fully completed were received from all three institutions. The researchers believe that the collected data, regardless of average return rate of the questionnaire provides a representative picture that would address the problem, aim and research questions of this study.

The data was captured and analysed with Microsoft Excel spread sheets. These spread sheets were used to generate the graphs, tables and charts from the collected quantitative data. The descriptive statistics included the tallying of frequencies in the calculation of percentages.

The qualitative data was transcribed into a word-processing document and analysed using "continuous comparison of data" (Walliman, 2005). This technique allowed the use of strategies for "labelling collected data, discovering categories and naming the data” (Schurink, Fouché, \& De Vos, 2011). It was used to compare all the sentences of the transcribed data to discover the similarities and identify differences in the participants' responses. Finally, a theme that represents a group of sentences or paragraphs was chosen from these views.

Two major limitations affected this study. Firstly, it did not include the students' views because it focused on the input (lecturers' practice of ESD), producing a desired output (students' understanding of ESD concept). The second limitation was the availability of lecturers. Due to their busy schedule, some of them were not willing to take part in the study. Others did not complete the questionnaires as requested, resulting in return rate of $52 \%$, even after having been assured of anonymity.

\section{Presentation and Interpretation of Results}

The presentation of data reflects the demographic information, the lecturers' views regarding the need to integrate ESD into their subjects, the barriers hindering implementation of ESD in HEIs and how the barriers are addressed to effectively implement ESD in Namibian HEIs.

\subsection{Demographic Information of the Participants}

Participants were asked to indicate their gender. The results are given in Figure 1.

The majority (56\%) of the respondents were males as compared to $46 \%$ females. Nonetheless, the numbers of males versus females varied from institution to institution with UNAM having a much larger number of males as compared to females. Furthermore, Figure 1 shows that more responses were obtained from UNAM lecturers than from the other two HEIs.

The respondents were also asked to indicate the department in which they worked in the respective HEIs. The 
results are given in Figure 2.

The majority of the respondents were lecturers in the Faculty of Education, accounting for 58\%. This was followed by lecturers from engineering-related faculty. The remaining lecturers were from the social sciences (13\%) and natural science-related faculties (10\%). The results show that a number of different course offerings in the three HEIs were represented in the study.

\subsection{The Lecturers' Views Regarding the Need to Incorporate ESD in Namibian Higher Education Institutions}

The lecturers were asked whether they recognised the need to incorporate ESD concepts into their subjects. Ninety per cent of the respondents were of the view that all lecturers should be able to integrate ESD and in this way be responsible for spreading the benefits thereof to the whole community through the students they taught. However, $10 \%$ stated that ESD should only be implemented by the Natural Science lecturers. The results seem to suggest that a few were not inclined to incorporate ESD into their courses.

Another question asked to the respondents was whether they had taught ESD concepts in their courses. The results are given in Table 1.

Table 1 shows that the majority (57\%) of respondents taught ESD concepts in their courses while 31\% indicated that they did not. A few (12\%) respondents were not sure whether they did. These results therefore indicate that some of the lecturers were not sure what ESD was about.

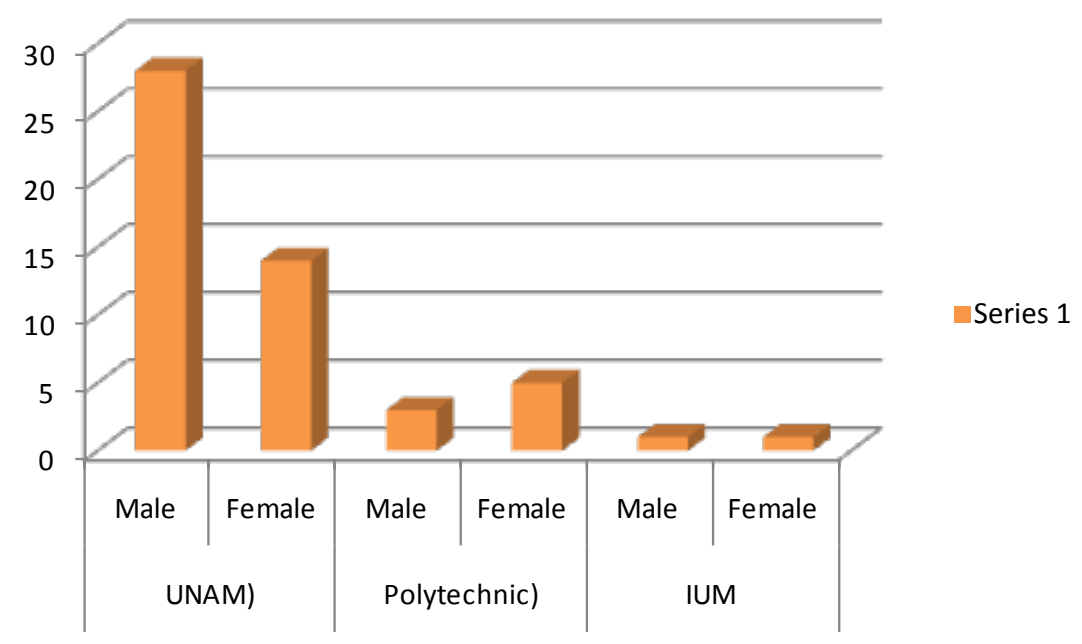

Figure 1. Participants by gender per institution.

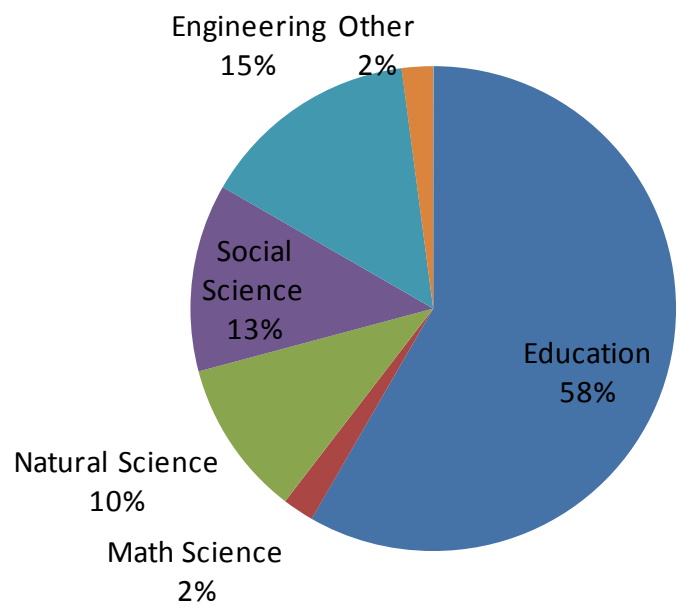

Figure 2. Classification of respondents by department. 


\subsection{The Barriers That Hinder the Implementation of ESD Concepts in HEIs}

The respondents were asked to specify whether barriers that hindered the implementation of ESD were of a dispositional, situational or institutional nature. The results are given in Table 2.

From Table 2 it is clear that all three types of barriers appeared to have impacted the respondents more or less equally. Nonetheless, the dispositional barriers were identified as the main barriers to the integration of ESD in Namibia's HEIs. This result seems to suggest that the lecturers did not incorporate ESD because they did not have an understanding of what ESD was about. Other lecturers mentioned the situational barriers which pertain to a lack of ability and skill to infuse ESD subjects. The institutional constraints refer to the rules, schedules and systems (Kanyimba \& Coetzer, 2011). These results seem to suggest that the strategy to address ESD must first address the HEIs, the individual lecturers and also provide teaching resources.

\subsection{How Should These Barriers Be Addressed to Effectively Implement ESD in Namibian HEIs?}

The lecturers were asked about what should be done to address the barriers to ESD in Namibian HEIs. The given strategies are set out in Table 3 .

Table 3 shows that training or staff development in ESD was identified by $27 \%$ of respondents. Integrating ESD concepts in existing courses and showing the importance of ESD also stand out because it these were identified by $20 \%$ and $11 \%$ of the respondents respectively. Other important strategies include team-teaching and curriculum development. However, these strategies would need lecturers who are trained to adequately deal with ESD. The other strategies mentioned relate to the need to provide financial support and develop an ESD policy. The lecturers also suggested the need for research on ESD-related matters. This should support the development of materials. These results seem to suggest the need to link ESD to the core function of teaching and research and the development of tools to guide its implementation.

\subsection{What Are the Strategies to Overcome Barriers to the Implementation of ESD in HEIs?}

An open-ended question was asked about the strategies that should be used to promote the integration of ESD concepts into the existing modules/courses. The results are shown in Table 4.

Table 4 shows that the main strategy to overcome the situational, dispositional and institutional barriers to implementing ESD in Namibian HEIs are training and knowledge provision. The second strategy suggested is

Table 1. Teaching of ESD concepts by the respondents $(\mathrm{N}=51)$.

\begin{tabular}{cccc}
\hline \multirow{2}{*}{ Response } & \multicolumn{2}{c}{ Frequency } & \multirow{2}{*}{ Totals } \\
\cline { 2 - 3 } & Males & Females & \\
\hline Yes & $(14) 28 \%$ & $(15) 29 \%$ & (29) $57 \%$ \\
No & $(12) 24 \%$ & (4) $8 \%$ & (16) $31 \%$ \\
Not sure & $(5) 10 \%$ & (1) $2 \%$ & (6) $12 \%$ \\
Totals & $\mathbf{( 3 1 )} \mathbf{6 1 \%}$ & $\mathbf{( 2 0 )} \mathbf{3 9 \%}$ & (51) $\mathbf{1 0 0} \%$ \\
\hline
\end{tabular}

Table 2. Nature of barriers encountered in the implementation of ESD in the HEIs.

\begin{tabular}{cccc}
\hline Type of barrier & Male & Female & Total \\
\hline Situational & $(14) 17 \%$ & $(12) 15 \%$ & (26) $32 \%$ \\
Dispositional & $(16) 20 \%$ & $(12) 15 \%$ & (28) $35 \%$ \\
Institutional & $(18) 22 \%$ & $(8) 10 \% \%$ & $2632 \%$ \\
No barriers & $(0) 0 \%$ & (2) $2 \%$ & (2) $2 \%$ \\
Totals & $(48) 59 \%$ & $(34) 41 \%$ & (82) $100 \%$ \\
\hline
\end{tabular}


Table 3. Strategies to overcome barriers to the implementation of ESD in HEIs.

\begin{tabular}{|c|c|c|c|}
\hline \multirow{2}{*}{ Strategy } & \multicolumn{2}{|c|}{ Frequency } & \multirow{2}{*}{ Total } \\
\hline & Male & Female & \\
\hline 1) Training or staff development in ESD & (17) $22 \%$ & (4) $5 \%$ & (21) $27 \%$ \\
\hline 2) Integrate ESD concepts into existing courses & (14) $18 \%$ & (2) $3 \%$ & (16) $21 \%$ \\
\hline 3) Show importance of ESD & (6) $8 \%$ & (10) 3\% & (16) $11 \%$ \\
\hline 4) Provide teaching/learning materials/resources on ESD & (2) $3 \%$ & (2) $3 \%$ & (4) $6 \%$ \\
\hline 5) Team-teaching of ESD concepts & (2) $3 \%$ & (2) $3 \%$ & (4) $6 \%$ \\
\hline 6) Develop curriculum that integrates ESD concepts & (3) $4 \%$ & (1) $1 \%$ & (4) $5 \%$ \\
\hline 7) ESD should be taught as a separate subject & (4) $5 \%$ & (0) $0 \%$ & (4) $5 \%$ \\
\hline 8) Provide more funding & (2) $3 \%$ & (1) $1 \%$ & (3) $4 \%$ \\
\hline 9) Carry out research on ESD & (1) $1 \%$ & (1) $1 \%$ & (2) $2 \%$ \\
\hline 10) Develop policy on ESD & (2) $3 \%$ & (0) \% & (2) $3 \%$ \\
\hline 11) Allocate more time on timetable for teaching ESD & (2) $3 \%$ & (0) $0 \%$ & (2) $3 \%$ \\
\hline 12) Give incentives to those involved in ESD & (1) $1 \%$ & (0) $0 \%$ & (1) $1 \%$ \\
\hline Totals & (56) $71 \%$ & (23) $29 \%$ & (79) $100 \%$ \\
\hline
\end{tabular}

Table 4. Strategies to overcome barriers to implementation of ESD in HEIs.

\begin{tabular}{|c|c|}
\hline Training & $\begin{array}{l}\text { - "Proper training should be given to all educators in carrying out ESD activities } \\
\text { - "Thd that includes teaching". } \\
\text { " workshop but a course that is examinable must be thought of seriously". } \\
\text { " "Teachers coming from institution of HL should possess skills and knowledge that will } \\
\text { help them to guide the community in which they are going to teach on the issue of SD" } \\
\text { "We all need ESD knowledge if we need to protect our environments, and we cannot do } \\
\text { better without an education". }\end{array}$ \\
\hline $\begin{array}{l}\text { Provide ESD in primary } \\
\text { and secondary schools }\end{array}$ & $\begin{array}{l}\text { - "Concepts about sustainable development must already be taught at the early grade } \\
\text { levels. Teaching about relevant values can be the starters". }\end{array}$ \\
\hline Show the importance of ESD & $\begin{array}{l}\text { - "ESD can be a reliable programme only if all stakeholders are interested and see its } \\
\text { importance to our daily lives". }\end{array}$ \\
\hline
\end{tabular}

about the need to include ESD in primary and secondary school curricula. This would ensure that students come to HEIs with greater knowledge and a background about ESD concepts. The third suggestion is dispositional because it supports the need to show the importance of ESD to the lecturers and members of management.

\section{Discussions}

The Namibian HEIs that participated in the study included the University of Namibia (all its campuses), the Polytechnic of Namibia and the International University of Management. The ecosystem theory was the basis on which the assessment of barriers was carried out because researchers considered it necessary in the promotion of the interdisciplinary teaching of ESD in Namibian higher education (Sterling, 2001). These suggestions by the lecturers could assist in the implementation of ESD in Namibia because it could be used to inform postUNDESD developments in Namibian HEIs.

\subsection{The Lecturers' Views Regarding the Need to Incorporate ESD into Namibian HEIs}

UNESCO (2004) states that ESD is interdisciplinary and holistic and that learning for sustainable development should be embedded in the whole curriculum. Based on the data presented in this report, it seems that lecturers in Namibian HEIs hold this view because the majority of them see the need to incorporate ESD in the curricu- 
lum. However, not all lecturers were involved in the implementation of ESD concepts in their respective subjects, courses and modules. It should be noted that all educators need to become active agents as far promoting ESD in Namibia's HEIs. Nicolaides (2006) holds the same view that active educator involvement in environmental matters brings about positive changes in the general publics. The need to promote ESD as an interdisciplinary subject is consistent with the view that interaction of human society and ecosystems are complex multiple linkages and not suited to disciplinary analysis (Dale \& Newman, 2006). From this discussion it can be concluded that ESD in Namibian HEIs does not cut across the various courses or modules and that there are lecturers who did not incorporate it into their courses because they lack background pertaining thereto.

\subsection{The Barriers That Hinder the Implementation of ESD Concepts in HEIs}

Observation of Table 3 it is clear that the barriers that hinder the implementation of ESD in Namibian HEIs are dispositional, situational and institutional. This argument is consistent with the thesis of Dawe, Jucker and Martin (2005). These authors also assert that barriers to ESD include a lack of expertise, limited institutional drive and commitment and perceived irrelevancy by the academic staff. Based on the data presented in Table 2, it can be concluded that barriers that affect the implementation of ESD in Namibian higher education are related to institutions, to individual lecturers and also to teaching resources.

\subsection{How Should These Barriers Be Addressed to Effectively Implement ESD in Namibian HEIs?}

Tables 3 and 4 clearly indicate that the need to promote the importance of ESD in HEIs will depend to a large extent on making lecturers and respective institutions to be change agents and role models. Nicolaides (2006) states that faculties should be role-models for their students and the society in which they live. They should inspire and motivate the idea of sustainability and environmental awareness and actively seek the transformation of society. The authors therefore are of the opinion that training and other strategies as mentioned in Tables 3 and 4 must promote the necessity to be role-models for students and society. Based on the data presented in Tables 3 and 4, the following can be concluded:

- There is a need for Namibian HEIs to lead the agenda for ESD.

- Training should include the lecturers and administrative officials of Namibian HEIs.

- Administrative and other officials should be convinced about the need to provide funding for ESD.

- Lecturers must have resources that can be used to teach ESD concepts to their students.

- The importance of ESD for the present and future generation needs to be demonstrated to ensure understanding by students and larger community.

- ESD must be linked to the core function of teaching and research.

\section{Recommendations}

Namibian HEIs should be assisted to think in terms of the ecosystem-orientated pedagogy because it helps to build bridges between higher education courses and ESD. The first step in addressing the situational, institutional and dispositional barriers is to convince members of management in Namibian HEIs of the importance of ESD. It should be noted that an academic institution committed to sustainability would help students understand the roots of environmental degradation and motivate them to seek environmentally sustainable practices, while also teaching them the roots of today's injustices by fully integrating justice and humaneness (Clugston \& Calder, 2007). It is therefore important that the management of HEIs in Namibia be urged to appoint champions of education for sustainability and key administrative leaders also be persuaded to adopt ESD in their research, teaching and operation (Clugston \& Calder, 2007; Shriberg, 2002; Alshuwaikhat \& Abubakar, 2008). The ESD requires champions who must assist each faculty with the process of building bridges between their respective courses and ESD.

ESD development must be reflected in the policies of the relevant institutions (Sterling, 2001). The researchers therefore recommend that all Namibian HEIs be urged to adopt a policy on ESD. This policy should be transformed into an action plan and also be used as an extension for the on-the-job training of lecturers and management members. This policy and its action plan could help to address institutional barriers because the institutions would have guidelines as to how practically address ESD in their operations. 
ESD presupposes that those who teach consider themselves learners (Walls \& Jickling, 2002). This suggests that ESD requires continual on-the-job training for lecturers who could be guided by transmitted and transformative ESD (Ashley, 2005; Wals, 2003). Transmission is about delivering facts, skills and values to lecturers (Jickling \& Wals, 2008) and can be synonymous with ideological imposition, outright proselytising or even gentler steering, but it remains undemocratic and indoctrinating (Qablan, ALRuz, \& Al-Omari, 2009). This study recommends transformative-like on-the-job training because it acknowledges the views of the lecturers about the status of education for sustainable development in their courses (Mezirow, 2003). The following pedagogical characteristics, borrowed from Wals and Jickling (2002), must be emphasised in Namibian HEIs:

- Move from individual learning to collaborative learning.

- Move from theory-dominated learning to praxis-orientated learning.

- Move from sheer knowledge accumulation to problematic issue-orientation.

- Move from content-oriented learning to self-regulative learning.

- Move from institutional staff-based learning to learning with and from outsiders (Wals \& Jickling, 2002).

These pedagogical characteristics are important in driving education for sustainable development towards the ecosystem-orientated pedagogy because they emphasise collaborative learning and praxis-oriented learning. In this way the situational and dispositional barriers could be addressed.

To implement ESD as outlined above requires that materials be developed (Thomas, 2004). HEIs around the world have published case studies that cover nearly all areas of Namibian HEIs, as set out in Figure 1 (Kamp. 2006; Mogensen \& Schnack, 2010, Lehtonen, 2004; Lundegård \& Wickman, 2007). Lecturers in Namibian higher education must be urged to download these case studies and use them for to guide the implementation of ESD in Namibia's HEIs while considering the realities of the Namibian higher education context. Secondly, the lecturers should be urged to use the examples from these case studies to develop their own resources to support the teaching of ESD in Namibian higher education. It is emphasised that the resources which are thus developed must address the local, regional and international dimensions of ESD.

\section{Conclusion}

In this paper the barriers to the implementation of Education for Sustainable Development in Namibian HEIs were outlined. The findings of this study have shown that ESD is hampered by dispositional, situational and institutional barriers. It is emphasised that education towards sustainability needs to be approached with an integrated effort from Namibian HEIs. This approach allows the creation of space for all subjects in Namibian higher education to contribute to the minimisation of environmental destruction, be it in the mining and woodland areas, water and air pollution, waste management, biodiversity, declining fish resources, overgrazing and bush encroachment. Adopting the ecosystem-orientated pedagogy as a conceptual framework to drive the implementation of ESD calls for all lecturers to get on the ESD band wagon. The strength of ESD will come through diverse disciplinary contributions woven together to accomplish a shared vision of sustainability.

\section{Acknowledgements}

Special thanks are extended to the University of Namibia, Research and Publication Office which provided funding to undertake this study.

\section{References}

Alshuwaikhat, H. M., \& Abubakar, I. (2008). An Integrated Approach to Achieving Campus Sustainability: Assessment of the Current Campus Environmental Management Practices. Journal of Cleaner Production, 16, 1777-1785. http://dx.doi.org/10.1016/j.jclepro.2007.12.002

Anker, P. (2002). The Context of the Ecosystem Theory. Ecosystems, 6, 611-613. http://dx.doi.org/10.1007/s10021-002-0106-8

Ashley, M. (2005). Tensions between Indoctrination and the Development of Judgement: The Case against Early Closure. Environmental Education Research, 11, 187-197. http://dx.doi.org/10.1080/1350462042000338351

Austin, M. (2007). Species Distribution Models and Ecological Theory: A Critical Assessment and Some Possible New Approaches. Ecological Modelling, 200, 1-19. http://dx.doi.org/10.1016/j.ecolmodel.2006.07.005

Barth, M., Godemann, J., Rieckmann, M., \& Stoltenberg, U. (2007). Developing Key Competencies for Sustainable Development in Higher Education. International Journal of Sustainability in Higher Education, 8, 416-430. 
http://dx.doi.org/10.1108/14676370710823582

Clugston, R. M., \& Calder, W. (2007). Critical Dimensions of Sustainability in Higher Education. http://www.ulsf.org/pdf/Critical_dimensions_SHE.pdf

Cortese, A. D., \& McDonough, W. (2003). Education for Sustainability: Accelerating the Transition to Sustainability through Higher Education. The National Council for Science and the Environment Third National Conference on Science, Policy and the Environment: Education for a Sustainable and Secure Future, Washington DC, 30-31 January 2003.

Cotton, D., Bailey, I., Warren, M., \& Bissell, S. (2009). Revolutions and Second-Best Solutions: Education for Sustainable Development in Higher Education. Studies in Higher Education, 34, 719-733. http://dx.doi.org/10.1080/03075070802641552

Creswell, J. W. (2009). Research Design. Quantitative, Qualitative and Mixed Approaches (3rd ed.). London: Sage.

Cutter, S. L., \& Renwick, W. H. (2004). Exploitation, Conservation, Preservation. A Geographic Perspective of Natural Resource Use. Hoboken, NJ: John Wiley.

Dale, A., \& Newman, L. (2006). Sustainable Development, Education and Literacy. International Journal of Sustainability in Higher Education, 6, 351-362. http://dx.doi.org/10.1108/14676370510623847

Dawe, G., Jucker, R., \& Martin, S. (2005). Sustainable Development in Higher Education: Current Practice and Future Developments a Report for the Higher Education Academy. Heslington: Higher Education Academy.

Donald, D. R., Lazarus, S., \& Lolwana, P. (2006). Educational Psychology in Social Context (3rd ed.). Oxford: Oxford University Press.

Down, L. (2006). Addressing the Challenges of Mainstreaming Education for Sustainable Development in Higher Education. International Journal of Sustainability in Higher Education, 7, 390-399. http://dx.doi.org/10.1108/14676370610702190

Earth Summit (1992). The United Nations Conference on Environment and Development, Rio De Janeiro. London: International Institute for Environment and Development.

Gall, M. D., Gall, J. P., \& Borg, W. R. (2011). Applying Educational Research (6th ed.). Boston, MA: Pearson.

Glaser, M. (2006). The Social Dimension in Ecosystem Management: Strengths and Weaknesses of Human-Nature Mind Maps. Human Ecology Review, 13, 122-142.

Government of the Republic of Namibia (2004). Namibia Vision 2030, Policy Framework for Long-Term National Development. Windhoek: Office of the President.

Jickling, B., \& Wals, A. E. J. (2008). Globalization and Environmental Education: Looking beyond Sustainable Development. Journal of Curriculum Studies, 40, 1-21. http://dx.doi.org/10.1080/00220270701684667

Johnson, B., \& Christensen, L. (2004). Educational Research (2nd ed.). Boston, MA: Pearson.

Jørgensen, S. E. (2002). Integration of Ecosystem Theories: A Pattern. Ecology \& Environment, 3, 365-396. http://dx.doi.org/10.1007/978-94-010-0381-0_16

Kamp. L. (2006). Engineering Education in Sustainable Development at Delft University of Technology. Journal of Cleaner Production, 14, 928-931. http://dx.doi.org/10.1016/j.jclepro.2005.11.036

Kanyimba, A. T., \& Coetzer, I. A. (2011). The Integration of Sustainability Education in Namibian Colleges of Education. Africa Education Review, 8, 133-147. http://dx.doi.org/10.1080/18146627.2011.586157

Lehtonen. M. (2004). The Environmental-Social Interface of Sustainable Development: Capabilities, Social Capital, Institutions. Ecological Economics, 49, 199-214. http://dx.doi.org/10.1016/j.ecolecon.2004.03.019

Lundegård, I., \& Wickman, P. O. (2007). Conflicts of Interest: An Indispensable Element of Education for Sustainable Development. Environmental Education Research, 13, 1-15. http://dx.doi.org/10.1080/13504620601122566

Mertler, C. C., \& Charles, C. M. (2008). Introduction to Educational Research (7th ed.). Boston, MA: Pearson.

Mezirow, J. (2003). Transformative Learning as Discourse. Journal of Transformative Education, 1, 58-63. http://dx.doi.org/10.1177/1541344603252172

Ministry of Education (2009). The National Curriculum for Basic Education. Okahandja: National Institute of Education Development.

Ministry of Environment \& Tourism (2002). Namibia's National Assessment Report for the World Summit on Sustainable Development. Windhoek: UNDP \& Ministry of Environment and Tourism.

Ministry of Information and Broadcasting (1990). The Constitution of the Republic of Namibia. Windhoek: Ministry of Information and Broadcasting.

Ministry of Wildlife, Conservation and Tourism (MWCT) (1992). Namibia's Green Plan to Secure Present and Future Generations of a Safe and Healthy Environment and a Prosperous Economy. Windhoek: MWCT.

Mogensen, F., \& Schnack, K. (2010). The Action Competence Approach and the “New” Discourses of Education for Sus- 
tainable Development, Competence and Quality Criteria. Environmental Education Research, 16, 59-74. http://dx.doi.org/10.1080/13504620903504032

Namibia National Commission for UNESCO (NATCOM) (2008). Outputs of the First National Consultative Seminar on Education for Sustainable development in Namibia. In Proceedings of the Workshop Report (pp. 1-25). Windhoek: NATCOM.

Nicolaides, A. (2006). The Implementation of Environmental Management towards Sustainable Universities and Education for Sustainable Development as an Ethical Imperative. International Journal of Sustainability in Higher Education, 7, 414-424. http://dx.doi.org/10.1108/14676370610702217

Nielsen. S. N. (2007). What Has Modern Ecosystem Theory to Offer to Cleaner Production, Industrial Ecology and Society? The Views of an Ecologist. Journal of Cleaner Production, 15, 1639-1653.

http://dx.doi.org/10.1016/j.jclepro.2006.08.008

Polytechnic of Namibia (2012a). Prospectus: School of Natural Resources and Tourism. Windhoek: Polytechnic of Namibia.

Polytechnic of Namibia (2012b). Prospectus: School of Health and Applied Sciences. Windhoek: Polytechnic of Namibia.

Polytechnic of Namibia (2012c). Prospectus: College for Open and Lifelong Learning. Windhoek: Polytechnic of Namibia.

Preisendörfer, P. (2008). Environmental Issues. In J. J. Bezuidenhout (Ed.), A Reader in Selected Social Issues (pp. 176-188). Pretoria: Van Schaik.

Qablan, A. M., ALRuz, J., \& Al-Omari, A. (2009). Education for Sustainable Development: Liberation or Indoctrination? An Assessment of Faculty Members' Attitudes and Classroom Practices. International Journal of Environmental \& Science Education, 4, 401-417. http://www.ijese.com/IJESE_v4n4_Oablan.pdf

Rickinson, M., Lundholm, C., \& Hopwood, N. (2009). Environmental Learning. Insights from Research into Student Experience. London: Springer.

Rowe, D. (2007). Education for a Sustainable Future. Science, 317, 323-324. www.sciencemag.org http://dx.doi.org/10.1126/science.1143552

Schurink, W., Fouché, C. B., \& De Vos, A. S. (2011). Qualitative Data Analysis and Interpretations. In A. S. De Vos, H. Strydom, C. B. Fouché, \& C. S. L. Delport (Eds.), Research at Grass Roots. To the Social Sciences and Human Service Professions (4th ed., pp. 397-423). Pretoria: Van Schaik.

Seehausen, O. (2007). Chance, Historical Contingency and Ecological Determinism Jointly Determine the Rate of Adaptive Radiation. Heredity, 99, 361-363.

Shriberg, M. (2002). Toward Sustainable Management: The University of Michigan Housing Division’s Approach. Journal of Cleaner Production, 10, 41-45. http://dx.doi.org/10.1016/S0959-6526(01)00021-X

Sipos, Y., Battisti, B., \& Grimm, K. (2006). Achieving Transformative Sustainability Learning: Engaging Head, Hands and Heart. International Journal of Sustainability in Higher Education, 9, 68-86. http://dx.doi.org/10.1108/14676370810842193

Sterling, S. (2001). Sustainable Education-Putting Relationship Back into Education. http://ecommunities.tafensw.edu.au/pluginfile.php/12139/mod_page/content/145/Stephen\%20Stirling\%20article.pdf

Sterling, S. (2003). Whole System Thinking as a Basis for Paradigm Change in Education. Explorations in the Context of Sustainability. Ph.D. Thesis, Bath: University of Bath.

Thomas, I. (2004). Sustainability in Tertiary Curricula: What Is Stopping It Happening? International Journal of Sustainability in Higher Education, 5, 33-47. http://dx.doi.org/10.1108/14676370410517387

UNESCO (2004). United Nations Decade of Education for Sustainable Development: Draft International Implementation Scheme. Paris: UNESCO. http://portal.unesco.org/education/

University of Namibia (UNAM) (2011a). Prospectus: Faculty of Education. Windhoek: UNAM.

University of Namibia (UNAM) (2011b). Prospectus: Faculty of Humanities and Social Sciences. Windhoek: UNAM.

University of Namibia (UNAM) (2011c). Prospectus: Faculty of Law. Windhoek: UNAM.

University of Namibia (UNAM) (2011d). Prospectus: Faculty of Science. Windhoek: UNAM.

Walliman, N. (2005). Your Research Project (2nd ed.). London: Sage.

Wals, A. E. J. (2003). Sustainability as an Outcome of Transformative Learning. In J. Holmberg, \& B. E. Samulesson (Eds.), Drivers and Barriers for Implementing Sustainable Development in Higher Education (pp. 103-119). Paris: UNESCO.

Wals, A. E. J., \& Jickling, B. (2002). Sustainability in Higher Education: From Doublethink and Newspeak to Critical Thinking and Meaningful Learning. International Journal of Sustainability in Higher Education, 3, 221-232.

http://dx.doi.org/10.1108/14676370210434688

Walsh, M. (2001). Research Made Real: A Guide for Students. Cheltenham: Nelson Thornes. 